
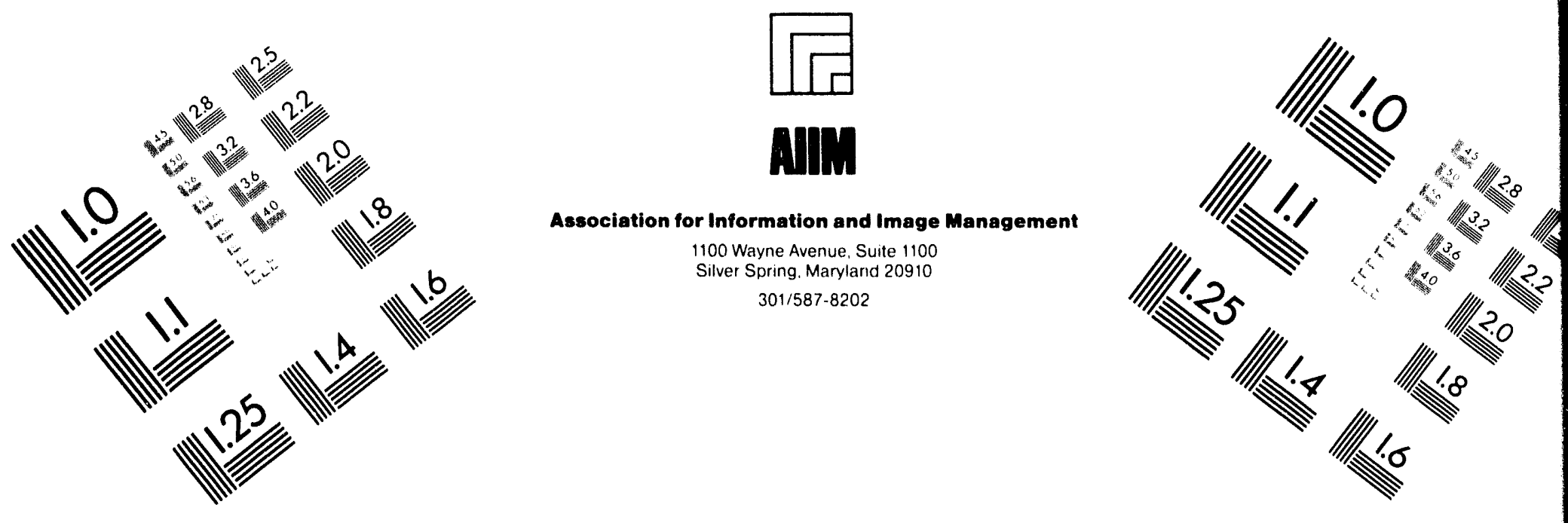

\title{
Centimeter
}

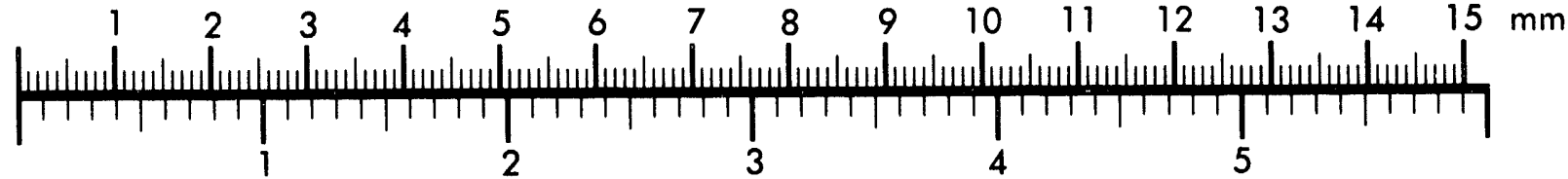

Inches
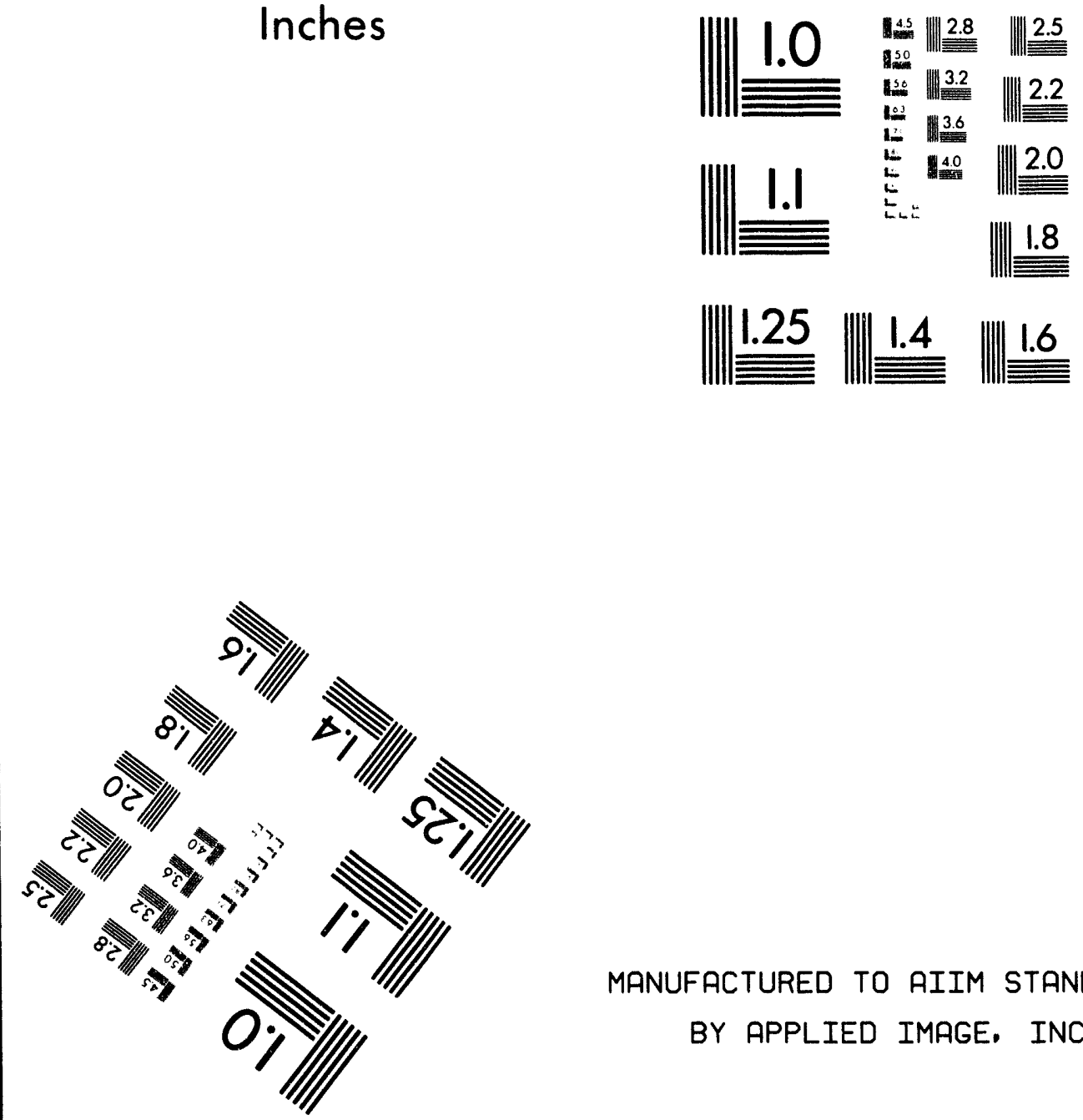

MANUFACTURED TO AIIM STANDARDS

BY APPLIED IMAGE. INC.

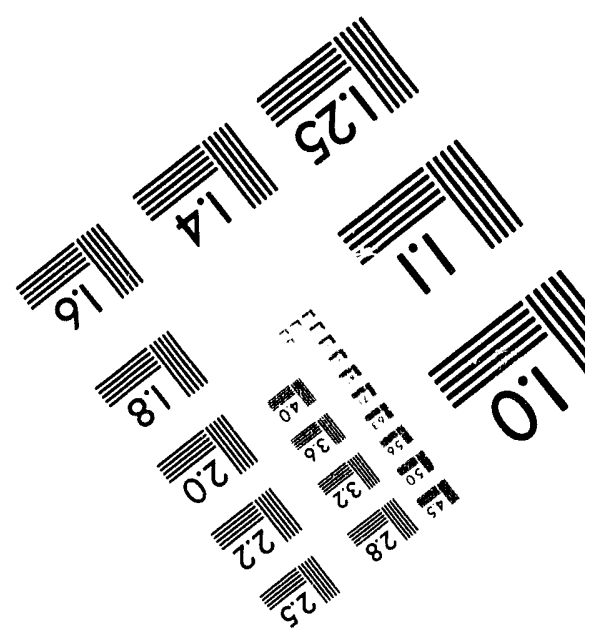



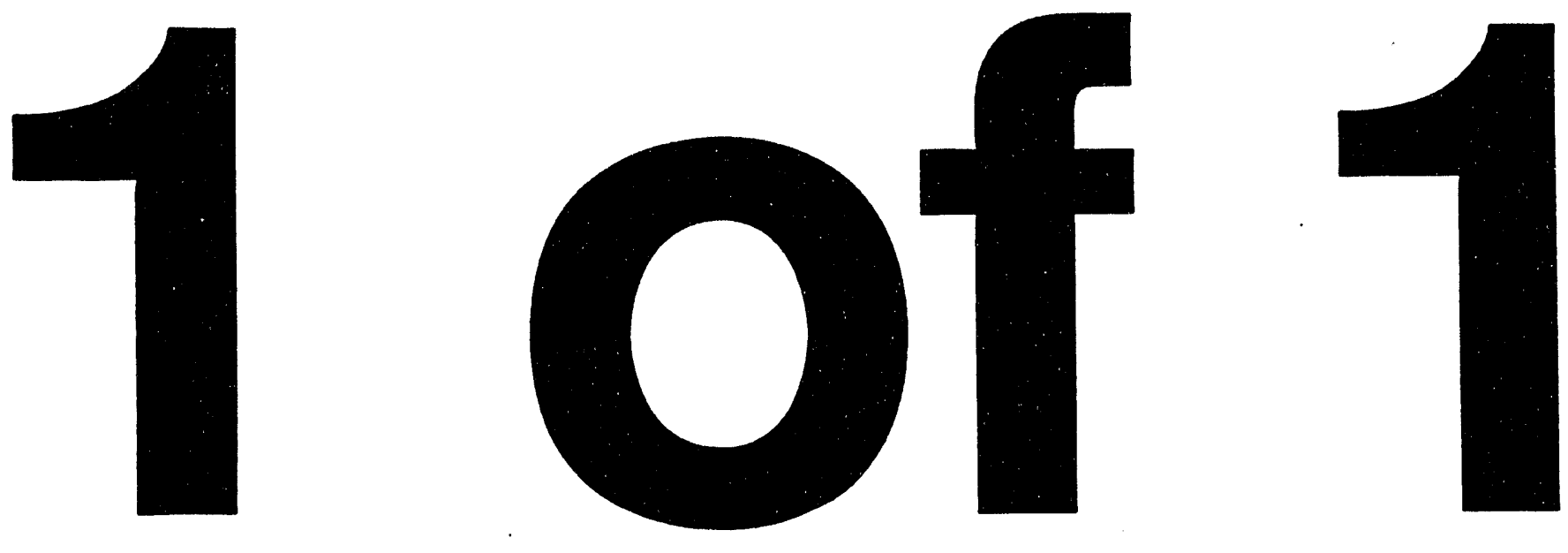


\section{Supercritical Water Oxidation Test Bed Effluent Treatment Study}

C. M. Barnes

Published April 1994

Idaho National Engineering Laboratory

EG\&G Idaho, Inc.

Idaho Falls, Idaho 83415

Prepared for the

U.S. Department of Energy

Office of Environmental Restoration and Waste Management

Under DOE Idaho Operations Office

Contract DE-AC07-76ID01570 


\section{SUPERCRITICAL WATER OXIDATION TEST BED EFFLUENT TREATMENT STUDY}

Prepared by

CmBane

C. M. Barnes, Senior Engineering Specialist Chemical and Process Engineering

Reviewed by

Caclyp Shapen

C. Shapiro, Engineering Specialist Mechanical Engineering and Design

Approved by

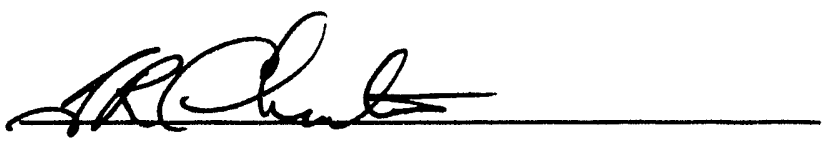

T. R. Charlton, Project Manager

Waste Technology Development
$4-25-94$

Date

$4-25-94$

Date

$4-26-89$

Date 


\begin{abstract}
This report presents effluent treatment options for a 50 gph Supercritical Water Test Unit. Effluent compositions are calculated for eight simulated waste streams, using different assumed cases. Variations in effluent composition with different reactor designs and operating schemes are discussed. Requirements for final effluent compositions are briefly reviewed. A comparison is made of two general schemes. The first is one in which the effluent is cooled and effluent treatment is primarily done in the liquid phase. In the second scheme, most treatment is performed with the effluent in the gas phase. Several unit operations are also discussed, including neutralization, mercury removal, and evaporation.
\end{abstract}




\section{SUMMARY AND RECOMMENDATIONS}

The U.S Department of Energy (DOE) is evaluating Supercritical Water Oxidation (SCWO) as a means to treat mixed hazardous and radioactive wastes currently stored or generated at various DOE sites. A $50 \mathrm{gph}$ test bed is currently being designed that will provide evaluation data for SCWO technology. The test bed will have the flexibility to test multiple SCWO reactor designs, and will contain all feed, effluent and support systems required in a SCWO process.

Effluent treatment from the supercritical water reactor is required in order to comply with environmental regulations, to enable the test bed to operate under Idaho National Engineering Laboratory (INEL) permits and to permit disposal of wastes from the tests.

The test bed will need flexibility to handle 10 simulated wastes that vary widely in form, composition and heating value, to interface with different reactor designs that potentially operate at different temperatures and have different means of heat transfer, and also to handle a wide range of oxygen flow rates. This flexibility sets demands on the effluent treatment system because of the wide range of effluent flowrates, the range of compositions of reactor effluent, and the different types of hazardous materials that are expected in the effluents of the different waste series.

Air pollution standards set requirements for different types of effluent treatment. The very low emission limits on hazardous materials such as arsenic compounds set standards for solids removal equipment from the gaseous effluent. The form of mercury in the effluent from Test Series 1 is not certain, and removal of mercury vapor from offgas and mercury compounds from liquid effluent may be required. Several of the organic feed liquids (e.g., benzene, methanol, and tributyl phosphate) have low air emission limits and will require a means of removal for cases of incomplete oxidation in the supercritical reactor. While high destruction efficiency is expected, the scope of testing includes determining operating limits or other cases where oxidation may be incomplete. A removal efficiency of $99 \%$ of the $\mathrm{HCl}$ generated in Test Series 4 is required, based on maximum TRIM०SOL in the feed, to meet the air emission limit. Other acid-gases, and aqueous acids and bases formed in the process will also require neutralization.

Mercury can be removed from the gaseous effluent by adsorption on activated carbon. Impregnation of the carbon with sulfur enhances removal efficiency. An activated carbon bed in the gaseous effluent line can provide removal of other air pollutants as well, both hazardous metal solids and organic vapors. Removal of mercury from the liquid effluent can be accomplished through ion exchange or precipitation.

Of the commonly used neutralization agents, sodium hydroxide is favored because of its solubility, the solubilities of neutralization products, and the amount of reagent required. Ammonia also shows advantages, but would require additional equipment to recover the excess ammonia needed to ensure complete neutralization.

The specific requirements for waste minimization of the test bed operation need further investigation. Liquid and solid wastes from many of the test series are not expected to be hazardous, although waste minimization may still be desirable. Evaporation offers a versatile and well-proven means to achieve a large reduction in waste volume. Of the many types of evaporators available two types are most applicable for the test bed. A pot, kettle, or pan evaporator is a single vessel design 
that would likely operate in a batch or semibatch mode. A forced circulation evaporator can generally achieve higher concentrations of solids in the bottoms product while minimizing scaling and deposition.

Conventional SCWO effluent treatment systems cool the effluent through heat exchange or quench prior to depressurization. This results in a partially condensed fluid, which, when acid gases are present, is highly corrosive. For a SCWO unit treating mixed waste, effluent treatment would then be needed for both gaseous and liquid phases. If condensation can be avoided by minimizing effluent cooling and depressurizing in low velocity control valves, effluent treatment would be simpler, more able to separate radionuclides from salt wastes, and very likely more economical in both operating and capital costs. However, because of concerns of corrosion and plugging of these control valves, it is recommended that such a system be designed and tested. 


\section{CONTENTS}

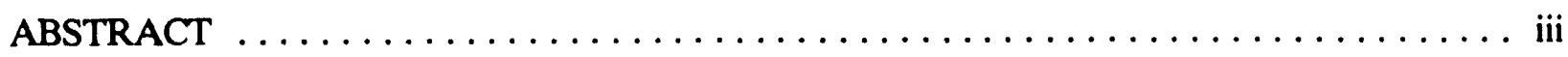

SUMMARY AND RECOMMENDATIONS $\ldots \ldots \ldots \ldots \ldots \ldots \ldots \ldots \ldots \ldots \ldots$

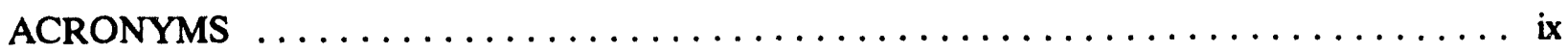

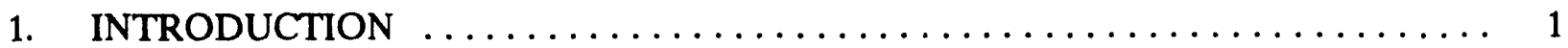

2. REACTOR EFFLUENT COMPOSITION $\ldots \ldots \ldots \ldots \ldots \ldots \ldots \ldots \ldots \ldots$

3. EFFLUENT STANDARDS $\ldots \ldots \ldots \ldots \ldots \ldots \ldots \ldots \ldots \ldots \ldots \ldots \ldots \ldots$

4. ALTERNATIVE TREATMENT SYSTEMS $\ldots \ldots \ldots \ldots \ldots \ldots \ldots \ldots$

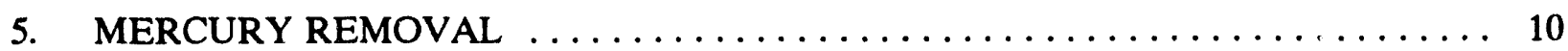

5.1 Mercury Removal from Gaseous Effluent $\ldots \ldots \ldots \ldots \ldots \ldots \ldots \ldots \ldots \ldots$

5.2 Mercury Removal From Liquid Effluent $\ldots \ldots \ldots \ldots \ldots \ldots \ldots \ldots \ldots \ldots \ldots$

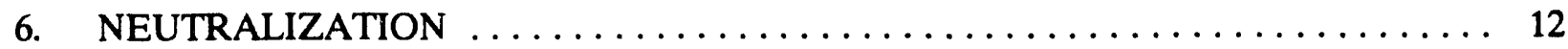

7. EVAPORATION $\ldots \ldots \ldots \ldots \ldots \ldots \ldots \ldots \ldots \ldots \ldots \ldots \ldots \ldots \ldots \ldots$

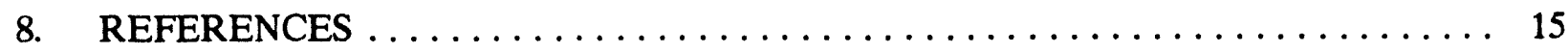

Appendix A Calculation of Feed and Effluent Compositions for Eight Test Waste Cases ... A-1 Appendix B Test Bed Worst Case Air Emissions $\ldots \ldots \ldots \ldots \ldots \ldots \ldots \ldots \ldots \ldots$ B-1

\section{TABLES}

1. Effect of waste and oxygen concentrations on effluent composition $\ldots \ldots \ldots \ldots$

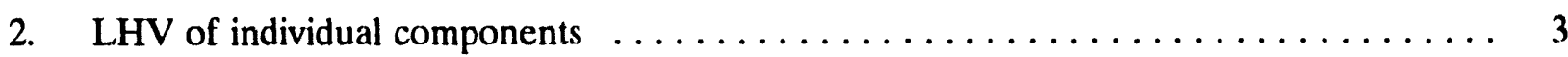

3. Effluent for Test Series 3, 4, and 8 based on neutralization with caustic $\ldots \ldots \ldots 4$

4. RCRA concentration of contaminants for the toxicity characteristic $\ldots \ldots \ldots \ldots$

5. Pollutants likely to be present in one or more tests $\ldots \ldots \ldots \ldots \ldots \ldots \ldots$ 


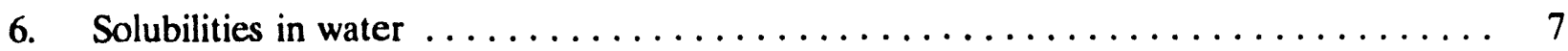

7. Comparison of neutralization agents $\ldots \ldots \ldots \ldots \ldots \ldots \ldots \ldots \ldots \ldots \ldots \ldots \ldots$

8. Amount of solids present in test bed effluent $\ldots \ldots \ldots \ldots \ldots \ldots \ldots \ldots \ldots \ldots$ 


\section{ACRONYMS}

DOE

INEL

LHV

PWA

RCRA

SCWO
U.S. Department of Energy

Idaho National Engineering Laboratory

lower heating value

process waste assessment

Resource Conservation and Recovery Act

Supercritical Water Oxidation 


\section{SUPERCRITICAL WATER OXIDATION TEST BED EFFLUENT TREATMENT STUDY}

\section{INTRODUCTION}

The U.S Department of Energy (DOE) is evaluating Supercritical Water Oxidation (SCWO) as a means to treat mixed hazardous and radioactive wastes, currently stored or generated at various DOE sites. A $50 \mathrm{gph}$ test bed is currently being designed, which will provide evaluation data for SCWO technology. The test bed will have the flexibility to test multiple SCWO reactor designs, and will contain all feed, effluent and support systems required in a SCWO process.

Effluent treatment from the Supercritical Water Reactor is required in order to comply with environmental regulations, to enable the test bed to operate under Idaho National Engineering Laboratory (INEL) permits, and to allow disposal of wastes from the tests.

The purposes of this report is to: (a) provide definition of the effluent, (b) to determine and propose alternative treatment schemes, and (c) to provide an evaluation of treatment alternatives at a general level. More detailed evaluations and selection of the test bed effluent treatment system will be done by the Test Bed Design team. 


\section{REACTOR EFFLUENT COMPOSITION}

The reactor effluent composition will depend on:

- The composition of simulated waste being tested

- The concentration of waste in water being fed to the reactor

- The type and amount of oxidizer used

- The efficiency of organic destruction in the reactor

- The amount of corrosion in the reactor

- The type and amount, if any, of neutralization agents added in or upstream of reactor.

Ten simulated DOE wastes have been defined for testing in the test bed. ${ }^{1}$ Eight of these 10 , Series 1 through 8, have been given priority, and serve as the design basis for the test bed. ${ }^{2}$ The eight wastes include organic liquids and solids, with Resource Conservation and Recovery Act (RCRA)-hazardous metals, surrogate radionuclides, and nonhazardous salts added. All of the simulated test wastes are mixtures of components. Actual tests may depart from these definitions, both in preliminary tests in which feed compositions are simplified, or in later tests to determine effects of waste stream variability.

The test bed design will be reviewed for its capability to treat Test Series 9, which is a halogenated solvents waste. Test Series 10 is a waste sludge, and modifications would be expected to be required in the test bed to handle the high inorganic solids content of this waste.

One set of feed and effluent compositions is given in Appendix A, Table 3 (feed) and Table 4 (effluent). These compositions are based on: (a) the eight waste series as defined in Reference 2, (b) a concentration of waste in water corresponding to a heating value of $1500 \mathrm{Btu} / \mathrm{b}$, (c) oxygen of three times the stoichiometric requirement, (d) complete organic destruction, (e) no corrosion products in the reactor, and ( $f$ ) no neutralization. The effluent compositions given in Table 4 of Appendix A, represent one set of limiting cases, and also a basis for recalculating compositions for departures from the above assumptions.

Flows and compositions of other cases also need to be considered in the design of an effluent treatment system. The amount of waste in water will vary with reactor design, and over the course of testing a given waste series. To estimate the effect of this variation, effluent compositions were calculated for different cases of methanol and oxygen concentrations and are given in Table 1.

To enable calculation of other cases of reactor effluent, the heating values of the test waste series are given in Table 1 of Appendix A, and the stoichiometry of oxidation reactions of test waste components is given in Table 2 of Appendix A.

Heating values (LHV) of individual components not shown in Appendix A, Table 1, are found in Table 2. 
Table 1. Effect of waste and oxygen concentrations on effluent composition.

\begin{tabular}{lccccc}
\hline \multirow{2}{*}{$\begin{array}{c}\text { Methanol, wt\% of } \\
\text { water plus waste }\end{array}$} & $\begin{array}{c}\text { Oxygen, \% of } \\
\text { stoichiometric }\end{array}$ & Water & $\mathrm{CO}_{2}$ & $\mathrm{O}_{2}$ & Total \\
\hline $3.3(300 \mathrm{Btu} / \mathrm{b})$ & 105 & 418.2 & 18.8 & 1.0 & 438.0 \\
3.3 & 200 & 418.2 & 18.8 & 20.5 & 457.5 \\
3.3 & 300 & 418.2 & 18.8 & 41.0 & 478.0 \\
$9.9(900 \mathrm{Btu} / \mathrm{lb})$ & 105 & 421.4 & 56.4 & 3.1 & 480.9 \\
9.9 & 200 & 421.4 & 56.4 & 61.6 & 539.4 \\
9.9 & 300 & 421.4 & 56.4 & 123.2 & 601.0 \\
$16.5(1500 \mathrm{Btu} / \mathrm{lb})$ & 105 & 424.6 & 94.1 & 5.1 & 523.8 \\
16.5 & 200 & 424.6 & 94.1 & 102.7 & 621.4 \\
16.5 & 300 & 424.6 & 94.1 & 205.4 & 724.1 \\
\hline
\end{tabular}

Table 2. LHV of individual components.

\begin{tabular}{ll}
\hline Methanol & $9,078 \mathrm{Btu} / \mathrm{lb}$ \\
Acetone & $12,513 \mathrm{Btu} / \mathrm{lb}$ \\
Polyethylene & $18,650 \mathrm{Btu} / \mathrm{lb}$ \\
Polyvinyl chloride & $7,920 \mathrm{Btu} / \mathrm{lb}$ \\
Cellulose & $7,500 \mathrm{Btu} / \mathrm{b}$ \\
Ethylene glycol & $7,784 \mathrm{Btu} / \mathrm{bb}$ \\
\hline
\end{tabular}

The heating values vary slightly with temperature. Heating values of benzene, methanol, acetone and ethylene glycol were calculated at $600^{\circ} \mathrm{C}$, and found to be within $0.6 \%$ of standard values, which are at $298 \mathrm{~K}$.

It is expected that different reactor designs and reactor/preheater configurations will differ in the maximum heating value that can be tolerated, and hence in the effluent composition. If a preheater heated waste and water to $400^{\circ} \mathrm{C}$ and due to materials, the reactor temperature was limited to $650^{\circ} \mathrm{C}$, the feed would be limited to about $420 \mathrm{Btu} / \mathrm{lb}$, or $2.4 \%$ benzene in water. For this case, the exothermic heat of reaction is equivalent to that needed to heat the feed from 400 to $650^{\circ} \mathrm{C}$. If, for the same reactor, heat given off by the reaction is used to heat feeds from ambient temperature to $400^{\circ} \mathrm{C}$, the amount of waste can be increased to 8.6 to $10 \%$ benzene $(1500$ to $1720 \mathrm{Btu} / \mathrm{b})$. The lower value corresponds to stoichiometric oxygen and the higher to three times stoichiometric.

A platelet reactor is expected to be capable of a reactor outlet temperature higher than $650^{\circ} \mathrm{C}$. Heat released from the oxidation of $4 \%$ benzene in water would be equivalent to raising the temperature of the total feed from $400^{\circ}$ to $800^{\circ} \mathrm{C}$. Some increase in waste concentration for the platelet reactor is possible by feeding low temperature water to the porous wall reactor. However, 
since neither the inlet temperature needed to sustain oxidation, nor the maximum outlet temperature is known with certainty, the maximum concentration of waste to water for the platelet reactor will need to be determined by testing.

A neutralization agent for reactor effluent has not been selected, and it is possible that different ones could be used in different tests. The following are neutralization reactions for caustic, ammonia, and calcium hydroxide:

$$
\begin{aligned}
& \mathrm{NaOH}+\mathrm{HCl}=\mathrm{NaCl}+\mathrm{H}_{2} \mathrm{O} \\
& \mathrm{NH}_{3}+\mathrm{HCl}=\mathrm{NH}_{4} \mathrm{Cl} \\
& \mathrm{Ca}(\mathrm{OH})_{2}+2 \mathrm{HCl}=\mathrm{CaCl}_{2}+2 \mathrm{H}_{2} \mathrm{O}
\end{aligned}
$$

Products of neutralization of $\mathrm{SO}_{2}$ may be sulfates, sulfites, hydrogen sulfates, or hydrogen sulfites, depending on temperature, $\mathrm{pH}$ and amount of base added.

Table 3 shows the effluent for Test Series 3, 4, and 8, neutralized with $120 \%$ of stoichiometric $20 \%$ caustic, and using the same assumptions as Appendix A, Table 4.

Table 3. Effluent for Test Series 3,4 , and 8 based on neutralization with cau stic, $\mathrm{lb} / \mathrm{hr}$.

\begin{tabular}{lccc}
\hline & Series 3 & Series 4 & Series 8 \\
\hline $\mathrm{H}_{2} \mathrm{O}$ & 414.0 & 440.0 & 469.0 \\
$\mathrm{CO}_{2}$ & 140.2 & 104.7 & 101.2 \\
$\mathrm{O}_{2}$ & 258.1 & 216.2 & 225.1 \\
$\mathrm{~N}_{2}$ & - & 0.35 & - \\
Other & & & - \\
$\mathrm{Sm}_{2} \mathrm{O}_{3}$ & - & 0.145 & - \\
$\mathrm{Na}_{2} \mathrm{O}$ & - & 0.28 & - \\
$\mathrm{K}_{2} \mathrm{O}$ & - & 0.11 & - \\
$\mathrm{CaO}$ & - & 0.09 & - \\
$\mathrm{Fe}_{2} \mathrm{O}_{3}$ & - & 0.012 & - \\
$\mathrm{ZnO}$ & - & 0.005 & - \\
$\mathrm{NaCl}$ & 3.1 & 7.7 & - \\
$\mathrm{Na}_{2} \mathrm{SO}$ & - & 1.6 & 12.7 \\
$\mathrm{Na}_{3} \mathrm{PO}$ & - & - & 1.9 \\
$\mathrm{NaOH}$ & 0.42 & 1.3 & \\
\hline
\end{tabular}




\section{EFFLUENT STANDARDS}

A very brief review of regulatory standards for expected wastes was made in order to better determine effluent treatment alternatives. This review is not intended to be a process waste assessment (PWA) as required by EG\&G Company Procedure 8.1.

Liquid and solid effluents will be subject to disposal regulations contained in the RCRA, due to RCRA-hazardous components purposely added to feeds, and possibly products of corrosion or byproducts of oxidation. Air emissions will be subject to Idaho air pollution control rules.

Table 4 shows concentrations of contaminants that cause the waste to be classified as hazardous under RCRA. Only those contaminants are listed that are expected to be present in waste from the test bed.

It should be noted that hazardous waste is not expected to be produced for every test waste. Whether hazardous waste results from tests of Series 1 (in regard to benzene), 9, and 10 depends on the destruction efficiency achieved in the reactor. Tests with reactors constructed of a high-chromium alloy may result in chromium in the waste of Series $3,4,5,8,9$, and 10 as a result of corrosion.

Possible air pollutants in SCWO gaseous effluent are given in Appendix B, which also presents estimates of a worst case effluent composition. As for the liquid effluents, not all air pollutants are expected for every test waste. Pollutants that are those most likely to be present in one or more tests are given in Table 5.

Table 4. RCRA concentration of contaminants for the toxicity characteristic.

\begin{tabular}{llcc}
\hline $\begin{array}{l}\text { EPA hazardous waste } \\
\text { number }\end{array}$ & Contaminant & $\begin{array}{c}\text { Regulatory level } \\
\mathrm{mg} / \mathrm{L}\end{array}$ & $\begin{array}{c}\text { Test Series which may } \\
\text { contain contaminant }\end{array}$ \\
\hline D004 & Arsenic & 5.0 & 2 \\
D005 & Barium & 100.0 & 2 \\
D018 & Benzene & 0.5 & 1 \\
D006 & Cadmium & 1.0 & 2 \\
D019 & CCl & 0.5 & 9,10 \\
D007 & Chromium & 5.0 & 2, possibly others \\
D030 & 1,1-Dichloroethene & 0.7 & 9,10 \\
D008 & Lead & 5.0 & 2 \\
D009 & Mercury & 0.2 & 1 \\
D010 & Selenium & 1.0 & 2 \\
D011 & Silver & 5.0 & 2 \\
D039 & Tetrachloroethylene & 0.7 & 9 \\
\hline
\end{tabular}


Table 5. Pollutants likely to be present in one or more tests.

\begin{tabular}{|c|c|c|}
\hline Substance & $\begin{array}{l}\text { IDAPA emission limit } \\
\mathrm{lb} / \mathrm{hr}\end{array}$ & Circumstances of highest emissions \\
\hline Ammonia & 1.2 & Series 5 , low temperature \\
\hline Biphenyl & 0.1 & Series 1 , low conversion \\
\hline Dibutyl phosphate & 0.573 & Series 8 , low conversion \\
\hline Diethanolamine & 1.0 & Series 5 , low conversion \\
\hline Ethanolamine & 0.533 & Series 5 , low conversion \\
\hline Hydrogen chloride & 0.05 & Series 4 , incomplete neutralization \\
\hline Mercury & $0.001-0.007^{\mathrm{a}}$ & Series 1 \\
\hline Methyl alcohol & 2.6 & Series 2 , low conversion \\
\hline $\mathrm{P}_{2} \mathrm{O}_{5}$ & 0.067 & Series 8 , poor solids separation \\
\hline Tributyl phosphate & 0.167 & Series 8 , low conversion \\
\hline Arsenic compounds & 0.0000015 & Series 2 \\
\hline Benzene & 0.0008 & $\begin{array}{l}\text { Series } 1 \text {, less than } 99.993 \% \\
\text { destruction }\end{array}$ \\
\hline Cd \& compounds & 0.0018 & Series 2 \\
\hline $\mathrm{CCl}_{4}$ & 0.00044 & Series 9 and 10 , low conversion \\
\hline Tetrachloroethylene & 0.013 & Series 9 , low conversion \\
\hline
\end{tabular}

a. Emission limit depends on form of mercury.

The above standards set requirements for different types of effluent treatment. The very low emission limits on hazardous materials (e.g., arsenic compounds), set standards for solids removal equipment from the gaseous effluent. The form of mercury in the effluent from Case 1 is not certain, and removal of mercury vapor from offgas and mercury compounds from liquid effluent may be required. Several of the organic feed liquids such as benzene, methanol and tributyl phosphate, have low emission limits, and will require a means of removal for cases of incomplete oxidation in the supercritical reactor. A removal efficiency of $99 \%$ of the $\mathrm{HCl}$ generated in Series 4 is required, based on maximum TRIMOSOL in the feed, to meet the emission limit. Other acid gases, and aqueous acids and bases formed in the process will also require neutralization.

The following air pollutant emission standards set requirements for treatment of any gaseous waste released to the atmosphere:

- Removal of mercury

- Removal of solid pollutants (e.g., As and Cd compounds and $\mathrm{PO}_{5}$ ) 
- Removal of organic compounds (e.g., benzene, methanol and ethanolamine)

- Removal of acidic and alkaline gases (e.g., $\mathrm{HCl}$ and $\mathrm{NH}_{3}$ ).

RCRA regulations also set requirements for effluent treatment. Neutralization will succeed in rendering corrosive waste into nonhazardous waste for all test series but $1,2,9$, and 10, assuming no RCRA-hazardous metals in the effluent as a result of corrosion. Cases 1,9 , and 10 contain toxic organics as defined by RCRA. Although the solubilities of these compounds in water are "low", they are still orders of magnitude higher than the RCRA limit (see Table 6).

Thus for Test Series 1 containing benzene, the destruction efficiency will need to be greater than $99.999 \%$ to ensure the effluent water is not hazardous because of residual benzene in solution. This cannot be guaranteed for the test bed, since one goal of the unit is to define an envelope of operating conditions where this level of destruction is obtained. Therefore, for some tests, the waste will likely be hazardous. The same is true for series 9 and 10 .

A more thorough review of waste treatment in light of environmental waste minimization criteria needs to be performed. If reactors are tested, which are constructed of alloys containing chromium, hazardous waste could be minimized either by evaporation of the effluent to a small volume of solids or sludge, or by ion exchange to remove chromium. Removal of residual organics from liquid effluent is another means of hazardous waste minimization, either through recycle to the SCWO reactor or a separate treatment method. The major alternatives for treatment are air or steam stripping, and ozone/hydrogen peroxide/UV oxidation.

Table 6. Solubilities in water.

\begin{tabular}{lcc} 
Compound & $\begin{array}{c}\text { Solubility in water } \\
\mathrm{mg} /\end{array}$ & $\begin{array}{c}\text { RCRA limit } \\
\mathrm{mg} /\end{array}$ \\
\hline Benzene & 1,720 & 0.5 \\
1,1-Dichloroethylene & 210 & 0.7 \\
Tetrachloroethylene & 400 & 0.7 \\
\hline
\end{tabular}




\section{ALTERNATIVE TREATMENT SYSTEMS}

Existing SCWO pilot plants process effluent by first cooling, then depressurizing, and then, if needed, further processing gaseous and liquid effluent. Advantages of this general scheme are that energy can potentially be recovered from the high pressure fluid, it is amenable to oxygen and/or carbon dioxide recovery, and some equipment is of reduced size due to higher pressure compared to alternate schemes.

As the supercritical fluid is cooled, it's density gradually increases and water condenses. If the effluent was $100 \%$ water, a theoretical case, the density would increase 10-15 times and the fluid would become liquid without going through a phase boundary. In the real case with oxygen and $\mathrm{CO}_{2}$ present, the fluid will become mixed phase as it is cooled. As the fluid is cooled to and below the critical temperature, for effluents containing $\mathrm{HCl}$, the initial liquid condensate will be very concentrated in acid and hence very corrosive. If cooling is done by quench water, liquid is introduced into the system and the volume of liquid effluent increases by a factor of three or higher, which will increase the cost for the system.

After conling, the fluid is depressurized. Part of the condensed water, the amount depending on the temperature to which the fluid was cooled, will revaporize as the pressure is let down. Vaporization can damage the let-down valves because of cavitation and erosion.

Several advantages could result from an alternate system, in which cooling prior to pressure let down is minimized in order to avoid condensation:

- Avoiding the liquid phase will avoid electrochemical corrosion in the effluent cooler, and possibly also the let-down valves.

- In the gas phase, virtually all solids are in the solid phase and can be separated by gas-solid separation techniques. Separation becomes more difficult in a liquid in which many solids dissolve in part or in whole.

- Acid gases, with no liquid water present, are noncorrosive, and can be removed in separate operations from removal of solid radionuclides. This may permit a good separation between radionuclide solids and neutralization salts, which make solidification difficult. Once water condenses, however, both acid gases and radionuclides can dissolve into the aqueous phase.

- Little or no equipment may be needed to treat liquid effluent.

- Compared to the conventional system, which uses energy to first condense and then revaporize the water in the effluent in an evaporator, less energy is required.

- The high temperature, low pressure effluent is similar to off-gas from many other oxidation technologies, and treatment technology is well established. 
Based on steam properties only, it's estimated that the effluent could be cooled to about $450^{\circ} \mathrm{C}$ and then depressurized without any condensation. With oxygen and $\mathrm{CO}_{2}$ in the effluent, cooling to a lower temperature prior to depressurization may be possible. Following depressurization to about 240 psia, solids would be separated using conventional gas-solid separation techniques. If radionuclides were present, they would be expected to be removed with the solids, thereby separating them from salts that result from later neutralization.

Acid gases (e.g., $\mathrm{HCl}$ ) could then be removed by several techniques. The gas containing $\mathrm{HCl}$ is still hot enough to allow efficient operation of a spray drier, which would cool the gas, remove $\mathrm{HCl}$, and result in a dry salt waste and an offgas of oxygen and carbon dioxide. Other well-proven methods could also be used, (e.g., packed-bed scrubbers, tray scrubbers, fluidized bed scrubbers, venturi scrubbers, or spray towers). Mercury would likely need to be removed prior to acid-gas scrubbing, in order to avoid contaminating the salt waste with a RCRA-hazardous metal.

The major uncertainty in a gas phase effluent treatment system is whether valves exist which are capable of operating at high temperature with both acid gases and particulate, and without internal condensation. Condensation can likely be avoided by a low velocity control valve that forces the fluid to follow a tortuous path of right angle turns. Severe service valves of this type are manufactured by Control Components, Inc., and have been used in high pressure stream production and also in many applications in the oil and gas industry. 


\section{MERCURY REMOVAL}

The forms of mercury that will be in the effluent cannot be determined with certainty. When Modar tested a mercury containing feed in SCWO, they used mercury chloride in the feed and found mercury, assumed as the chloride, in the effluent. It was concluded that most of the mercury deposited since it was found in water and acid rinses. Mercury was not detected in the gaseous effluent. Based on municipal waste incinerators, mercury can be in offgas as chloride, oxide, or elemental mercury. Elemental mercury is sufficiently volatile that treatment of the offgas must be done for air pollution control.

\subsection{Mercury Removal from Gaseous Effluent}

Based on a very brief review of the literature, the best method of mercury removal appears to be activated carbon adsorption. Most experience with mercury remor .1 in gas streams comes from municipal waste incinerators, and mostly from Europe. Three methods are used:

1. Sodium sulfide injection

2. Activated carbon injection

3. Activated carbon beds.

The injection methods require a fabric filter, which is not planned for the test bed. There are other less-developed methods (e.g., selenium filters and scrubbing with cupric chloride). These offer no apparent advantage over the simple carbon bed.

A carbon bed has the advantage of being a well-developed, simple technology. It also would provide purification of the offgas for a variety of contaminants besides mercury, namely heavy metals, acid gases, and organics. If sized for only mercury removal, it would likely become loaded very quickly for upset cases of low conversion. Activated carbon impregnated with sulfur has been found to more effective than nonimpregnated carbon for adsorbing elemental mercury. ${ }^{3}$

For the SCWO test bed, if the gas is not saturated with water, moisture condensation will not occur in the carbon bed. Particulate removal should be done upstream of the bed to prevent the bed from plugging. Another advantage of using activated carbon for mercury removal is that the carbon will also remove other RCRA-hazardous and heavy metals as well as organics.

Air Pollution Control in Thermal Treatment, EGG-WTD-10038 4 lists the following suppliers of activated carbon for heavy metals (presumably including mercury):

CSC (919) 923-2911

P.O. Box 3

Bath, NC 27808 


\section{EVAPORATION}

Table 8 shows estimates of the amount of solids in test bed effluent, based on neutralization with $20 \%$ caustic, and material balances using $1500 \mathrm{Btu} / \mathrm{lb}$ feed. It should be recognized that actual effluents will have lower solids concentrations than shown in Table 8 because of quench water and lower organic feed contents.

From the above concentrations, a large volume reduction in waste is possible by evaporating water from the liquid effluent. Evaporators have been widely used in the nuclear industry for this purpose. However, assuming no hazardous organics or corrosion products, waste in most test series will not be hazardous, and benefits of volume reduction may be outweighed by the energy cost of an evaporator.

Evaporators can experience operational problems due to scaling, foaming, and entrainment, particularly for feeds of widely varying composition. Upstream filtration, chemical inhibitors, and proper selection of materials are needed to avoid corrosion. If used, chemical inhibitors would need to be nonhazardous.

Measures to limit scaling, which impedes heat transfer should also be considered. External rather than internal heating would allow heat transfer to the dilute feed rather than the concentrated liquid in the evaporator, thus reducing scale. Adding seed crystals as nuclei for precipitation is another method for limiting scaling.

Vapor-liquid separation devices at the vapor outlet improve disentrainment of liquid. These devices include: (a) disengagement chambers, (b) beds of packing, (c) cyclones, (d) baffles, and (e) demisters.

Table 8. Amount of solids present in test bed effluent.

\begin{tabular}{lccc}
\hline & $\begin{array}{c}\text { Solids produced } \\
\mathrm{lb} / \mathrm{hr}\end{array}$ & $\begin{array}{c}\text { Solids concentration } \\
\text { wt \% }\end{array}$ & RCRA-hazardous \\
\hline Series 1 & 0.04 & 0.01 & Yes \\
Series 2 & 2.08 & 0.50 & Yes \\
Series 3 & 3.1 & 0.67 & No \\
Series 4 & 9.94 & 2.10 & No \\
Series 5 & 3.82 & 0.92 & No \\
Series 6 & 1.73 & 0.46 & No \\
Series 7 & 1.59 & 0.38 & No \\
Series 8 & 12.7 & 2.7 & No \\
\hline
\end{tabular}


There are a large variety of evaporator designs. The majority utilize steam and are not readily adaptable to electric heating. Two common designs that can be used with electric heating are the pot, kettle, or pan evaporator and the forced circulation evaporator. Pot, kettle, or pan evaporators are single vessels, almost always operated in a batch or semibatch mode. Heat transfer and evaporation occur inside a vessel that is externally heated by a jacket or internally heated by a heating coil. Advantages of this design include its simplicity, low expense and space requirements compared to other designs, and, in some designs, the ability to easily remove and clean the heating coils. The major disadvantage is that, with the heating coils inside the vessel, deposition and fouling may be high.

Forced circulation evaporators can achieve higher concentrations of solids. Force circulation improves heat transfer as well as minimizing scaling and deposition. The mechanical energy may be from pumps or scrapers for deposition control. The heat transfer unit is usually separate from the evaporation and separation chamber. 


\section{REFERENCES}

1. C. M. Barnes, Mixed Waste Survey for the Supercritical Water Oxidation Program, EGG-WTD. 10984, November 1993, Appendix D.

2. C. Barnes, K. Garcia, R. Mizia, C. Shapiro, J. Svoboda, G. Thurston, Supercritical Water Oxidation Test Bed Functional and Operational Requirements, F/OR-232, February 1994.

3. AirTECH News, July 1993, p. 98. Contact Brian Gullett of EPA at (919) 541-1534 for more information on mercury removal with sulfur impregnated carbon.

4. G. L. Anderson, "Air Pollution Control in Thermal Treatment Systems," EGG-WTD-10038, May 1991

5. D. O. Reimann, "Mercury Output from Garbage Incineration," Waste Management \& Research 4, 1986, pp 45-56.

6. T. G. Brna, J. D. Kilgroe, "The Inpact of Particulate Emissions Control on the Control of Other MWC Emissions," J. Air Waste Management Association 40, September 1990, pp. 1324-1330. 
Appendix A

Calculation of Feed and Effluent Compositions for Eight Test Waste Cases 
sere ldaho, inc.

FORM EOO-2631:

(Rev. 01-92)

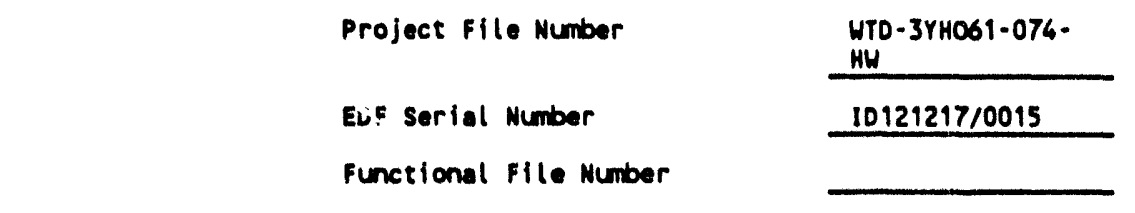

ENGINEERING DESIGN TILE

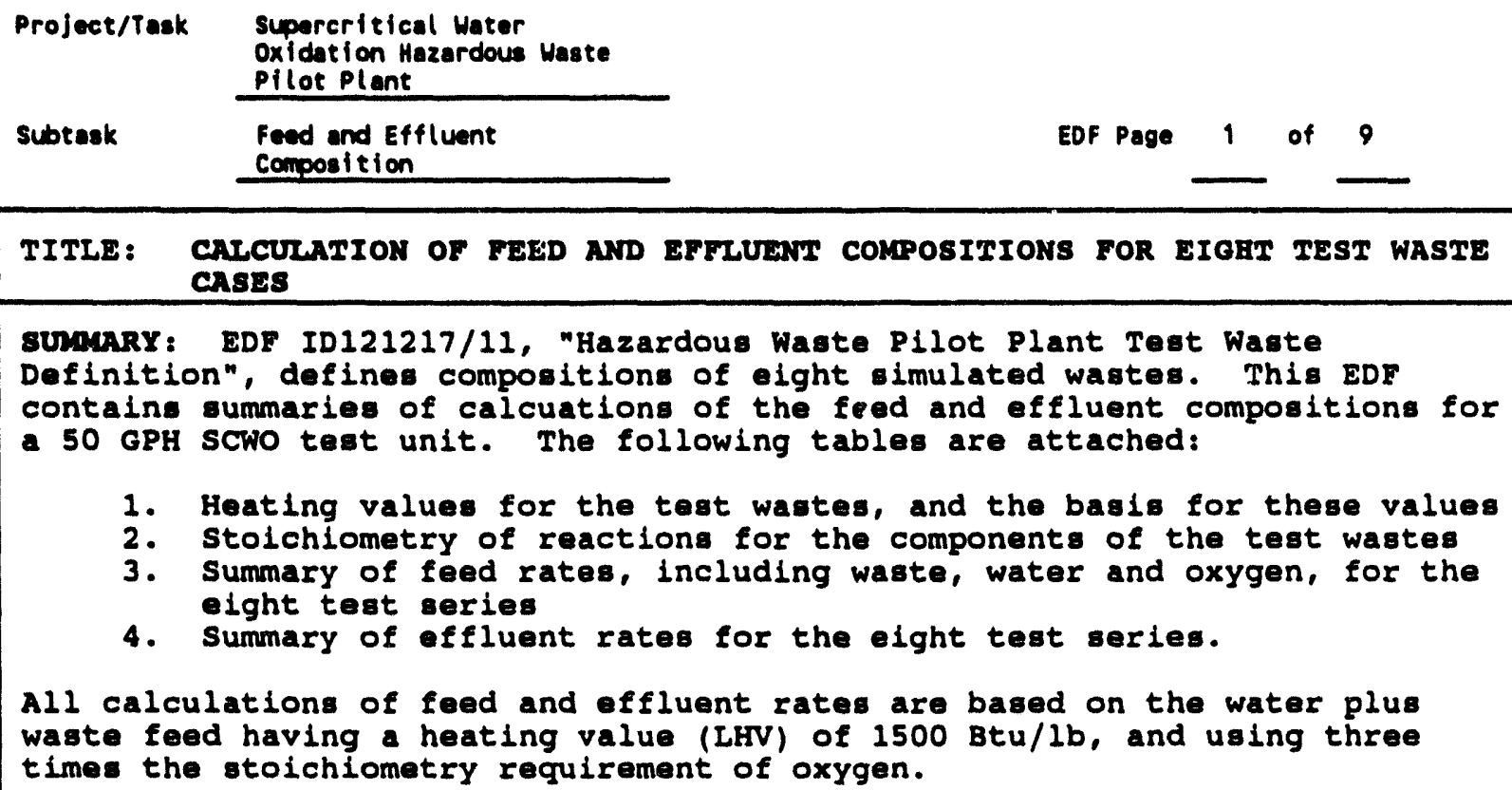

All calculations of feed and effluent rates are based on the water plus waste feed having a heating value (LHV) of $1500 \mathrm{Btu} / \mathrm{Lb}$, and using three times the stoichiometry requirement of oxygen.

Distribution (complete package ):

Distribution (aummary page only):

\begin{tabular}{|c|c|c|}
\hline $\begin{array}{ll}\text { Author } & \text { Dept. } \\
\text { c. M. Barnes } & \text { B820 } \\
\rho \text { Bune } & 3-24-94\end{array}$ & $\begin{array}{l}\text { Reyiewed Date } \\
\text { D. Nh: Giman } 3 / 24 / 94 \\
\text { Ginosar }\end{array}$ & 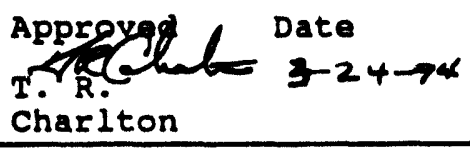 \\
\hline & $\begin{array}{l}\text { EG\&G } \\
\text { Review }\end{array}$ & $\begin{array}{l}\text { EG\&G } \\
\text { Approval }\end{array}$ \\
\hline
\end{tabular}

C. M. Barnes, J. M. Beller, T. R. Charlton, K. M. Garcla, R. W. Marshall, Jr., W. C. Reed, C. Shapiro, H. Welland

J. J. McCarthy 
Calculation of Feed and Effluent Composition for Eight Test Waste Cases Project WTD-3YH061-074, EDF ID 121217/0015

March 24, 1994

Page 2 of 9

TABLE 1

HEATING VALUES OF TEST SERIES

\begin{tabular}{|c|c|c|}
\hline Series & Heating Value, Btu/lb & Basis \\
\hline 1 & 17,450 & Benzene \\
\hline 2 & 10,800 & $50 \%$ Methanol, $50 \%$ Acetone \\
\hline 3 & 9,500 & $\begin{array}{l}60 \% \text { cellulose, } 35 \% \text { polyethylene, } 5 \% \text { PVC; } \\
\text { heating values for these estimated }\end{array}$ \\
\hline 4 & 15,000 & $\begin{array}{l}\text { Rounded from value given in Report } \\
\text { DOE/ID/12915-FIN for TRIMSOL }\end{array}$ \\
\hline 5 & 9,800 & $\begin{array}{l}50 \% \text { ethylene glycol }(7800 \mathrm{Btu} / \mathrm{lb}), 15 \% \\
\text { ethanolamines (approx. } 10,000 \mathrm{Btu} / \mathrm{lb}) \\
15 \% \text { motor oil (est. } 19.000 \mathrm{Btu} / \mathrm{lb} \text { ) }\end{array}$ \\
\hline 6 & 14,090 & Carbon \\
\hline 7 & 17,860 & Trimethylbenzene \\
\hline 8 & 15,670 & $\begin{array}{l}\text { Heating values for TBP and DBP estimated } \\
\text { to be } 12,200 \text { and } 11,600 \mathrm{Btu} / \mathrm{lb} \text { respectively, } \\
\text { and of diluent to be } 19,200 \mathrm{Btu} / \mathrm{lb}\end{array}$ \\
\hline
\end{tabular}

TABLE 2

STOICHOMETRY OF OXIDATION REACTIONS OF TEST WASTE COMPONENTS

\section{Test Series 1}

$\begin{array}{ll}\text { (benzene) } & \mathrm{C}_{6} \mathrm{H}_{6}+7.5 \mathrm{O}_{2}->6 \mathrm{CO}_{2}+3 \mathrm{H}_{2} \mathrm{O} \\ \text { (biphenyl) } & \mathrm{C}_{12} \mathrm{H}_{10}+14.5 \mathrm{O}_{2}->12 \mathrm{CO}_{2}+5 \mathrm{H}_{2} \mathrm{O} \\ \text { (diphenylamine) } & \mathrm{C}_{12} \mathrm{H}_{11} \mathrm{~N}+14.75 \mathrm{O}_{2}->12 \mathrm{CO}_{2}+5.5 \mathrm{H}_{2} \mathrm{O}+0.5 \mathrm{~N}_{2} \\ \text { (phenol) } & \mathrm{C}_{6} \mathrm{H}_{6} \mathrm{O}+7 \mathrm{O}_{2}-\mathrm{CO}_{2}+3 \mathrm{H}_{2} \mathrm{O} \\ \text { (diphenyl mercury) } & \mathrm{C}_{12} \mathrm{H}_{10} \mathrm{Hg}+14.5 \mathrm{O}_{2}-->12 \mathrm{CO}_{2}+5 \mathrm{H}_{2} \mathrm{O}+\mathrm{Hg}\end{array}$

Assumptions:

1. Complete oxidation

2. Elemental mercury is formed rather than oxides 
Calculation of Feed and Effluent Composition for Eight Test Waste Cases

Project WTD-3YH061-074, EDF ID 121217/0015

March 24, 1994

Table 2 continued

\section{Test Series 2}

$$
\begin{aligned}
& \text { (methanol) } \\
& \mathrm{CH}_{4} \mathrm{O}+1.5 \mathrm{O}_{2}->\mathrm{CO}_{2}+2 \mathrm{H}_{2} \mathrm{O} \\
& \text { (acetone) } \\
& \mathrm{C}_{3} \mathrm{H}_{6} \mathrm{O}+4 \mathrm{O}_{2} \ldots 3 \mathrm{CO}_{2}+3 \mathrm{H}_{2} \mathrm{O} \\
& \mathrm{Ba}\left(\mathrm{C}_{2} \mathrm{H}_{3} \mathrm{O}_{2}\right)_{2}+4 \mathrm{O}_{2}-->\mathrm{BaO}+4 \mathrm{CO}_{2}+3 \mathrm{H}_{2} \mathrm{O} \\
& \mathrm{Cd}\left(\mathrm{C}_{2} \mathrm{H}_{3} \mathrm{O}_{2}\right)_{2}+4 \mathrm{O}_{2}-->\mathrm{CdO}+4 \mathrm{CO}_{2}+3 \mathrm{H}_{2} \mathrm{O} \\
& \mathrm{Cr}\left(\mathrm{C}_{2} \mathrm{H}_{3} \mathrm{O}_{2}\right)_{3} \cdot \mathrm{H}_{2} \mathrm{O}+6 \mathrm{O}_{2} \cdots 0.5 \mathrm{Cr}_{2} \mathrm{O}_{3}+6 \mathrm{CO}_{2}+5.5 \mathrm{H}_{2} \mathrm{O} \\
& \mathrm{Pb}\left(\mathrm{C}_{2} \mathrm{H}_{3} \mathrm{O}_{2}\right)_{2}+4 \mathrm{O}_{2}-.>\mathrm{PbO}+4 \mathrm{CO}_{2}+3 \mathrm{H}_{2} \mathrm{O} \\
& \mathrm{Ag}\left(\mathrm{C}_{2} \mathrm{H}_{3} \mathrm{O}_{2}\right)+2 \mathrm{O}_{2}-->\mathrm{AgO}+2 \mathrm{CO}_{2}+1.5 \mathrm{H}_{2} \mathrm{O} \\
& \mathrm{Nd}\left(\mathrm{C}_{2} \mathrm{H}_{3} \mathrm{O}_{2}\right)_{3} \cdot \mathrm{H}_{2} \mathrm{O}+6 \mathrm{O}_{2} \ldots 0.5 \mathrm{Nd}_{2} \mathrm{O}_{3}+6 \mathrm{CO}_{2}+5.5 \mathrm{H}_{2} \mathrm{O} \\
& \mathrm{Sm}\left(\mathrm{C}_{2} \mathrm{H}_{3} \mathrm{O}_{2}\right)_{3} \cdot 3 \mathrm{H}_{2} \mathrm{O}+6 \mathrm{O}_{2} \cdots>0.5 \mathrm{Sm}_{2} \mathrm{O}_{3}+6 \mathrm{CO}_{2}+7.5 \mathrm{H}_{2} \mathrm{O} \\
& \mathrm{Eu}\left(\mathrm{C}_{2} \mathrm{H}_{3} \mathrm{O}_{2}\right)_{3}+6 \mathrm{O}_{2}-->0.5 \mathrm{Eu}_{2} \mathrm{O}_{3}+6 \mathrm{CO}_{2}+4.5 \mathrm{H}_{2} \mathrm{O}
\end{aligned}
$$

Assumptions:

1. Complete oxidation of methanol, acetone and acetates

2. Metals in acetates will form oxides

3. $\mathrm{As}_{2} \mathrm{O}_{3}$ and $\mathrm{SeO}_{2}$ will not react

\section{Test Series 3}

(PVC)

(polyethylene)

$\left(\mathrm{C}_{2} \mathrm{H}_{3} \mathrm{Cl}\right)_{\mathrm{n}}+2.5 \mathrm{n} \mathrm{O}_{2}-\cdots \mathrm{n}\left[2 \mathrm{CO}_{2}+\mathrm{HCl}+\mathrm{H}_{2} \mathrm{O}\right]$

(cellulose)

$$
\begin{aligned}
& \left(\mathrm{CH}_{2}\right)_{\mathrm{a}}+1.5 \mathrm{n} \mathrm{O}_{2}-\mathrm{>} n\left[\mathrm{CO}_{2}+\mathrm{H}_{2} \mathrm{O}\right] \\
& \left(\mathrm{C}_{6} \mathrm{H}_{10} \mathrm{O}_{5}\right)_{\mathrm{a}}+6 \mathrm{n} \mathrm{O}_{2}-\mathrm{n}\left[6 \mathrm{CO}_{2}+5 \mathrm{H}_{2} \mathrm{O}\right]
\end{aligned}
$$

\section{Assumptions}

1. Complete oxidation

2. All components except polyethylene and PVC can be represented by cellulose. 
Calculation of Feed and Effluent Composition for Eight Test Waste Cases

Project WTD-3YH061-074, EDF ID 121217/0015

March 24, 1994

Table 2 continued

\section{Test Series 4}

(Trimsol) $\quad \mathrm{C}_{20} \mathrm{H}_{37.5} \mathrm{O}_{1.65} \mathrm{Cl}_{1.1} \mathrm{~S}_{0.11} \mathrm{~N}_{0.22}+28.385 \mathrm{O}_{2}-->20 \mathrm{CO}_{2}+18.2 \mathrm{H}_{2} \mathrm{O}+$

$\mathrm{Na}+0.25 \mathrm{O}_{2} \rightarrow 0.5 \mathrm{Na}_{2} \mathrm{O}$

$\mathrm{Ca}+0.5 \mathrm{O}_{2} \rightarrow \mathrm{CaO}$

$\mathrm{K}+0.25 \mathrm{O}_{2} \rightarrow 0.5 \mathrm{~K}_{2} \mathrm{O}$

$\mathrm{Zn}\left(\mathrm{C}_{2} \mathrm{H}_{3} \mathrm{O}_{2}\right)_{2}+4 \mathrm{O}_{2}-\mathrm{ZnO}+4 \mathrm{CO}_{2}+3 \mathrm{H}_{2} \mathrm{O}$

$\mathrm{Fe}\left(\mathrm{C}_{2} \mathrm{H}_{3} \mathrm{O}_{2}\right)_{2} \cdot 4 \mathrm{H}_{2} \mathrm{O}+4.25 \mathrm{O}_{2}-->0.5 \mathrm{Fe}_{2} \mathrm{O}_{3}+4 \mathrm{CO}_{2}+7 \mathrm{H}_{2} \mathrm{O}$

Assumptions

1. Complete oxidation

2. Trimsol formula is estimated based on elemental analysis and typical petroleum oil carbon number

3. $\mathrm{Na}, \mathrm{Ca}, \mathrm{K}$ which are contained in Trimsol produce respective oxides

4. $\mathrm{S}$ in Trimsol goes to $\mathrm{SO}_{2} ; \mathrm{N}$ to $\mathrm{N}_{2}$

5. $\mathrm{Zn}$ and $\mathrm{Fe}$ go to oxides as shown above

\section{Test Series 5}

(ethylene glycol)

(MEA)

(DEA)

(TEA)

(motor oil)

(boric acid)

(PCB)

$$
\begin{aligned}
& \mathrm{C}_{2} \mathrm{H}_{6} \mathrm{O}_{2}+2.5 \mathrm{O}_{2}->2 \mathrm{CO}_{2}+3 \mathrm{H}_{2} \mathrm{O} \\
& \mathrm{C}_{2} \mathrm{H}_{7} \mathrm{ON}+3.25 \mathrm{O}_{2}->2 \mathrm{CO}_{2}+3.5 \mathrm{H}_{2} \mathrm{O}+0.5 \mathrm{~N}_{2} \\
& \mathrm{C}_{4} \mathrm{H}_{11} \mathrm{O}_{2} \mathrm{~N}+5.75 \mathrm{O}_{2}->4 \mathrm{CO}_{2}+5.5 \mathrm{H}_{2} \mathrm{O}+0.5 \mathrm{~N}_{2} \\
& \mathrm{C}_{6} \mathrm{H}_{15} \mathrm{O}_{3} \mathrm{~N}+8.25 \mathrm{O}_{2}->6 \mathrm{CO}_{2}+7.5 \mathrm{H}_{2} \mathrm{O}+0.5 \mathrm{~N}_{2} \\
& \mathrm{C}_{18} \mathrm{H}_{38}+27.5 \mathrm{O}_{2}-18 \mathrm{CO}_{2}+19 \mathrm{H}_{2} \mathrm{O} \\
& \mathrm{H}_{3} \mathrm{BO}_{3}->0.5 \mathrm{~B}_{2} \mathrm{O}_{3}+1.5 \mathrm{H}_{2} \mathrm{O} \\
& \mathrm{C}_{12} \mathrm{H}_{6} \mathrm{Cl}_{4}+12.5 \mathrm{O}_{2} \rightarrow>12 \mathrm{CO}_{2}+\mathrm{H}_{2} \mathrm{O}+4 \mathrm{HCl}
\end{aligned}
$$

Assumptions

1. Complete oxidation

2. Motor oil assumed to be as given above

3. Boric acid assumed, at supercritical conditions, to decompose to boric oxide and water

4. Motor oil typically has $\mathrm{Mg}, \mathrm{Zn}, \mathrm{Ca}$, and $\mathrm{S}$; it is assumed these are present as sulfates and undergo no reaction 
Calculation of Feed and Effluent Composition for Eight Test Waste Cases Project WTD-3YH061-074, EDF ID 121217/0015

March 24, 1994

Table 2 continued

Test Series 6

$\mathrm{C}+\mathrm{O}_{2} \ldots \mathrm{CO}_{2}$

$\mathrm{Al}\left(\mathrm{C}_{2} \mathrm{H}_{3} \mathrm{O}_{2}\right)_{3}+6 \mathrm{O}_{2} \cdots 0.5 \mathrm{Al}_{2} \mathrm{O}_{3}+6 \mathrm{CO}_{2}+4.5 \mathrm{H}_{2} \mathrm{O}$

$\mathrm{Ca}\left(\mathrm{C}_{2} \mathrm{H}_{3} \mathrm{O}_{2}\right)_{2}+4 \mathrm{O}_{2} \rightarrow \mathrm{CaO}+4 \mathrm{CO}_{2}+3 \mathrm{H}_{2} \mathrm{O}$

$\mathrm{Fe}\left(\mathrm{C}_{2} \mathrm{H}_{3} \mathrm{O}_{2}\right)_{2} \cdot 4 \mathrm{H}_{2} \mathrm{O}+4.25 \mathrm{O}_{2} \rightarrow 0.5 \mathrm{Fe}_{2} \mathrm{O}_{3}+4 \mathrm{CO}_{2}+7 \mathrm{H}_{2} \mathrm{O}$

$\mathrm{Ni}\left(\mathrm{C}_{2} \mathrm{H}_{3} \mathrm{O}_{2}\right)_{2}+4 \mathrm{O}_{2}-.>\mathrm{NiO}+4 \mathrm{CO}_{2}+3 \mathrm{H}_{2} \mathrm{O}$

$\mathrm{K}\left(\mathrm{C}_{2} \mathrm{H}_{3} \mathrm{O}_{2}\right)+2 \mathrm{O}_{2}->0.5 \mathrm{~K}_{2} \mathrm{O}+2 \mathrm{CO}_{2}+1.5 \mathrm{H}_{2} \mathrm{O}$

$\mathrm{Si}\left(\mathrm{C}_{2} \mathrm{H}_{3} \mathrm{O}_{2}\right)_{4}+8 \mathrm{O}_{2} \rightarrow \mathrm{SiO}_{2}+8 \mathrm{CO}_{2}+6 \mathrm{H}_{2} \mathrm{O}$

Assumptions

1. Complete oxidation

2. $\mathrm{NaF}, \mathrm{NaHSO}_{4}$, and $\mathrm{Na}_{2} \mathrm{SO}_{4}$ do not undergo reaction

3. Metals (as acetates) for oxides

\section{Test Series 7}

(trimethylbenzene) $\mathrm{C}_{9} \mathrm{H}_{12}+12 \mathrm{O}_{2}->9 \mathrm{CO}_{2}+6 \mathrm{H}_{2} \mathrm{O}$

$$
\begin{aligned}
& \mathrm{C}_{14} \mathrm{H}_{26} \mathrm{O}_{7} \mathrm{SNa}+18.25 \mathrm{O}_{2} \rightarrow 14 \mathrm{CO}_{2}+13 \mathrm{H}_{2} \mathrm{O}+\mathrm{SO}_{2}+0.5 \mathrm{Na}_{2} \mathrm{O} \\
& \mathrm{C}_{20} \mathrm{H}_{38} \mathrm{O}_{7} \mathrm{SNa}+27.25 \mathrm{O}_{2}->20 \mathrm{CO}_{2}+19 \mathrm{H}_{2} \mathrm{O}+\mathrm{SO}_{2}+0.5 \mathrm{Na}_{2} \mathrm{O} \\
& \mathrm{C}_{20} \mathrm{H}_{41} \mathrm{O}_{5}+27.75 \mathrm{O}_{2} \rightarrow 20 \mathrm{CO}_{2}+20.5 \mathrm{H}_{2} \mathrm{O}
\end{aligned}
$$

Assumptions

1. Complete Oxidation

2. Composition based on Atomlight formulation, Instagel expected to be similar

3. $20 \%$ of Atomlight composition unknown, know composition prorated

\section{Test Series 8}

$\left(\mathrm{C}_{4} \mathrm{H}_{9}\right)_{3} \mathrm{PO}_{4}+18 \mathrm{O}_{2} \rightarrow 12 \mathrm{CO}_{2}+\mathrm{H}_{3} \mathrm{PO}_{4}+12 \mathrm{H}_{2} \mathrm{O}$

$\left(\mathrm{C}_{4} \mathrm{H}_{9}\right)_{2} \mathrm{HPO}_{4}+12 \mathrm{O}_{2}->8 \mathrm{CO}_{2}+\mathrm{H}_{3} \mathrm{PO}_{4}+8 \mathrm{H}_{2} \mathrm{O}$

$\mathrm{C}_{12} \mathrm{H}_{26}+18.5 \mathrm{O}_{2} \rightarrow 12 \mathrm{CO}_{2}+13 \mathrm{H}_{2} \mathrm{O}$

Assumptions

1. Complete Oxidation

2. $\mathrm{C}_{10}-\mathrm{C}_{14}$ diluent taken to be all $\mathrm{C}_{12}$ 
Calculation of Feed and Effluent Composition for Eight Test Waste Cases Project WTD-3YH061-074, EDF ID 121217/0015

March 24, 1994

TABLE 3

FEED SUMMARY, LB/HR

Series $1 \quad$ Series $2 \quad$ Series $3 \quad$ Series 4

(Dilution,

\% Waste)

$\mathrm{H}_{2} \mathrm{O}$

$\mathrm{O}_{2}$

Other

Benzene

Diphenyl

Diphenylamine

Phenol

Diphenyl $\mathrm{Hg}$

$\mathrm{CH}_{3} \mathrm{OH}$

$\mathrm{CH}_{3} \mathrm{COCH}_{3}$

$\mathrm{As}_{2} \mathrm{O}_{3}$

$\mathrm{Ba}\left(\mathrm{C}_{2} \mathrm{H}_{3} \mathrm{O}_{2}\right)_{2}$

$\mathrm{Cd}\left(\mathrm{C}_{2} \mathrm{H}_{3} \mathrm{O}_{2}\right)_{2}$

$\mathrm{Cr}\left(\mathrm{C}_{2} \mathrm{H}_{3} \mathrm{O}_{2}\right)_{3} \cdot \mathrm{H}_{2} \mathrm{O}$

$\mathrm{Pb}\left(\mathrm{C}_{2} \mathrm{H}_{3} \mathrm{O}_{2}\right)_{2}$

$\mathrm{SeO}_{2}$

$\mathrm{Ag}\left(\mathrm{C}_{2} \mathrm{H}_{3} \mathrm{O}_{2}\right)$

$\mathrm{Nd}\left(\mathrm{C}_{2} \mathrm{H}_{3} \mathrm{O}_{2}\right)_{3} \cdot \mathrm{H}_{2} \mathrm{O}$

$\mathrm{Sm}\left(\mathrm{C}_{2} \mathrm{H}_{3} \mathrm{O}_{2}\right)_{3} \cdot 3 \mathrm{H}_{2} \mathrm{O}$

$\mathrm{Eu}\left(\mathrm{C}_{2} \mathrm{H}_{3} \mathrm{O}_{2}\right)_{3}$

Polyvinylchloride

Polyethylene

Cellulose

Trimsol

$\mathrm{Fe}\left(\mathrm{C}_{2} \mathrm{H}_{3} \mathrm{O}_{2}\right)_{2} \cdot 4 \mathrm{H}_{2} \mathrm{O}$

$\mathrm{Zn}\left(\mathrm{C}_{2} \mathrm{H}_{3} \mathrm{O}_{2}\right)_{2}$
380.7

327.2

28.6

5.4

0.9

0.9

0.072
(14.25) (15.75)

357.2

315.0

350.9

387.1
(10)

374.9

324.3
27.9

27.9

0.235

0.331

0.365

0.85

0.28

0.25

0.275

0.42

0.23

0.39

3.3

23.0

39.3

Basis and Assumptions:

1. $50 \mathrm{GPH}$ waste + water, $1500 \mathrm{Btu} / \mathrm{lb}, 3$ times stoichiometric $\mathrm{O}_{2}$

2. For series 3, all components except PVC and PE represented by cellulose

3. Formula for TRIMSOL assumed to be $\mathrm{C}_{20} \mathrm{H}_{37.5} \mathrm{O}_{1.65} \mathrm{Cl}_{1.1} \mathrm{~S}_{0.11} \mathrm{~N}_{0.22}$ plus $5000 \mathrm{ppm} \mathrm{Na}$, 1800 ppm Ca, 1800 ppm K 
Calculation of Feed and Effuent Composition for Eight Test Waste Cases Project WTD-3YH061-074, EDF ID 121217/0015 March 24, 1994

TABLE 3 continued

FEED SUMMARY, LB/HR

$\begin{array}{llll}\text { Series } 5 & \text { Series } 6 & \text { Series } 7 & \text { Series } 8\end{array}$

(Dilution,

\% Waste)

$\mathrm{H}_{2} \mathrm{O}$

$\mathrm{O}_{2}$

\section{Other}

$\begin{array}{lc}\mathrm{C}_{12} \mathrm{H}_{6} \mathrm{Cl}_{4} \text { (PCB) } & 0.032 \\ \mathrm{H}_{3} \mathrm{BO}_{3} & 3.2 \\ \mathrm{HOCH}_{2} \mathrm{CH}_{2} \mathrm{OH} & 31.9 \\ \mathrm{MEA} & 6.37 \\ \mathrm{DEA} & 6.37 \\ \mathrm{TEA} & 6.37 \\ \mathrm{Motor} \mathrm{Oil}^{*} & 9.6 \\ \mathrm{MgSO}_{4}^{*} & 0.08 \\ \mathrm{ZnSO}_{4}{ }^{*} & 0.03 \\ \mathrm{CaSO}_{4}{ }^{*} & 0.1\end{array}$

$\mathrm{Al}\left(\mathrm{C}_{2} \mathrm{H}_{3} \mathrm{O}_{2}\right)_{3}$

$\mathrm{Ca}\left(\mathrm{C}_{2} \mathrm{H}_{3} \mathrm{O}_{2}\right)_{2}$

$\mathrm{NaF}$

$\mathrm{Fe}\left(\mathrm{C}_{2} \mathrm{H}_{3} \mathrm{O}_{2}\right)_{2} \cdot 4 \mathrm{H}_{2} \mathrm{O}$

$\mathrm{Ni}\left(\mathrm{C}_{2} \mathrm{H}_{3} \mathrm{O}_{2}\right)_{2}$

$\mathrm{K}\left(\mathrm{C}_{2} \mathrm{H}_{3} \mathrm{O}_{2}\right)$

$\mathrm{Si}\left(\mathrm{C}_{2} \mathrm{H}_{3} \mathrm{O}_{2}\right)_{4}$

$\mathrm{NaHSO}_{4}$

$\mathrm{Na}_{2} \mathrm{SO}_{4}$

Carbon

Trimethylbenzene

Sodium diamyl sulfsuccinate

Sodium dioctyl sulfsuccinate

Polyoxyethylenelauryl ether

Tributyl Phosphate

Dibutyl Phosphate

$(10.7)$

371.9

364.4

322.6

0.032

31.9

6.37

6.37

6.37

9.6

0.08

0.1

1.7

0.11

0.01

0.59

0.08

0.07

0.25

0.59

0.31

44.6
28

1.4

2.8

2.8

$381.5 \quad 376.5$

$312.5 \quad 337.5$

* contained in motor oil, which is represented as $\mathrm{C}_{18} \mathrm{H}_{38}$ 
Calculation of Feed and Effluent Composition for Eight Test Waste Cases Project WTD-3YH061-074, EDF ID 121217/0015

March 24, 1994

TABLE 4

EFFLUENT SUMMARY, LB/HR

Series $1 \quad$ Series $2 \quad$ Series $3 \quad$ Series $4 \quad$ Series 5

$\begin{array}{lrrrrr}\mathrm{H}_{2} \mathrm{O} & 404.7 & 415.1 & 403.1 & 413.9 & 413.3 \\ \mathrm{CO}_{2} & 118.0 & 104.1 & 140.2 & 104.7 & 106.5 \\ \mathrm{O}_{2} & 218.1 & 210.0 & 258.1 & 216.2 & 215.0 \\ \mathrm{~N}_{2} & 0.07 & & & 0.35 & 2.9 \\ \mathrm{HCl} & & & 1.9 & 4.77 & 0.015 \\ \mathrm{SO}_{2} & & & & 0.84 & \end{array}$

Other

$\mathrm{Hg} \quad 0.04$

$\mathrm{As}_{2} \mathrm{O}_{3} \quad 0.235$

$\mathrm{BaO} \quad 0.2$

CdO 0.205

$\mathrm{Cr}_{2} \mathrm{O}_{3} \quad 0.258$

$\mathrm{PbO} \quad 0.201$

$\mathrm{SeO}_{2} \quad 0.251$

$\mathrm{Ag}_{2} \mathrm{O} \quad 0.209$

$\mathrm{Nd}_{2} \mathrm{O}_{3} \quad 0.202$

$\mathrm{Eu}_{2} \mathrm{O}_{3} \quad 0.211$

$\mathrm{Sm}_{2} \mathrm{O}_{3} \quad 0.105$

0.145

0.28

$\mathrm{Na}_{2} \mathrm{O}$

$\mathrm{K}_{2} \mathrm{O}$

0.11

$\mathrm{CaO}$

0.09

$\mathrm{Fe}_{2} \mathrm{O}_{3}$

$\mathrm{ZnO}$

0.012

0.005

$\mathrm{B}_{2} \mathrm{O}_{3}$

3.59

$\mathrm{MgSO}_{4}$

0.08

$\mathrm{ZnSO}_{4}$

0.03

$\mathrm{CaSO}_{4}$

0.1 
Calculation of Feed and Emuent Composition for Eight Test Waste Cases Project WTD-3YH061-074, EDF ID 121217/0015 March 24, 1994

TABLE 4 continued EFFLUENT SUMMARY, LB/HR

Series 6 Series $7 \quad$ Series 8

$\begin{array}{llll}\mathrm{H}_{2} \mathrm{O} & 373.0 & 412.5 & 420.3 \\ \mathrm{CO}_{2} & 166.9 & 107.1 & 101.2 \\ \mathrm{O}_{2} & 243.0 & 208.4 & 225.1 \\ \mathrm{~N}_{2} & & & \end{array}$

$\mathrm{HCl}$

$\mathrm{SO}_{2}$

$\mathrm{H}_{3} \mathrm{PO}_{4}$

0.065 7.57

Other

$\begin{array}{ll}\mathrm{Al}_{2} \mathrm{O}_{3} & 0.43 \\ \mathrm{CaO} & 0.04 \\ \mathrm{NaF} & 0.01 \\ \mathrm{Fe}_{2} \mathrm{O}_{3} & 0.19 \\ \mathrm{NiO} & 0.04 \\ \mathrm{~K}_{2} \mathrm{O} & 0.06 \\ \mathrm{SiO}_{2} & 0.06 \\ \mathrm{NaHSO}_{4} & 0.59 \\ \mathrm{Na}_{2} \mathrm{SO}_{4} & 0.31\end{array}$

$\mathrm{Na}_{2} \mathrm{O}$

0.31

Assumptions and basis

1. No neutralization of effluent

2. Metals in feed acetates oxidize to oxides

3. Metals in feed sulfates or bisulfates pass through the reactor without reaction

4. Sulfur in TRIMSOL forms $\mathrm{SO}_{2}$ in reactor

5. Boric acid dehydrates to boric oxide

6. TBP, DBP yield phosphoric acid

7. Sulfur in series 7 , scintillation fluid, forms $\mathrm{SO}_{2}$ in reactor 
Appendix B

Test Bed Worst Case Air Emissions

B-1 
Bese Idaho, Inc.

FOAM ECO-2631"

(Rev. 01-92)

Project File Number

WTD-3YHOS1-074-

EDF Serial Number

$10121217 / 0016$

Functional File Number

ENGINEERINO DEBIGN FILE

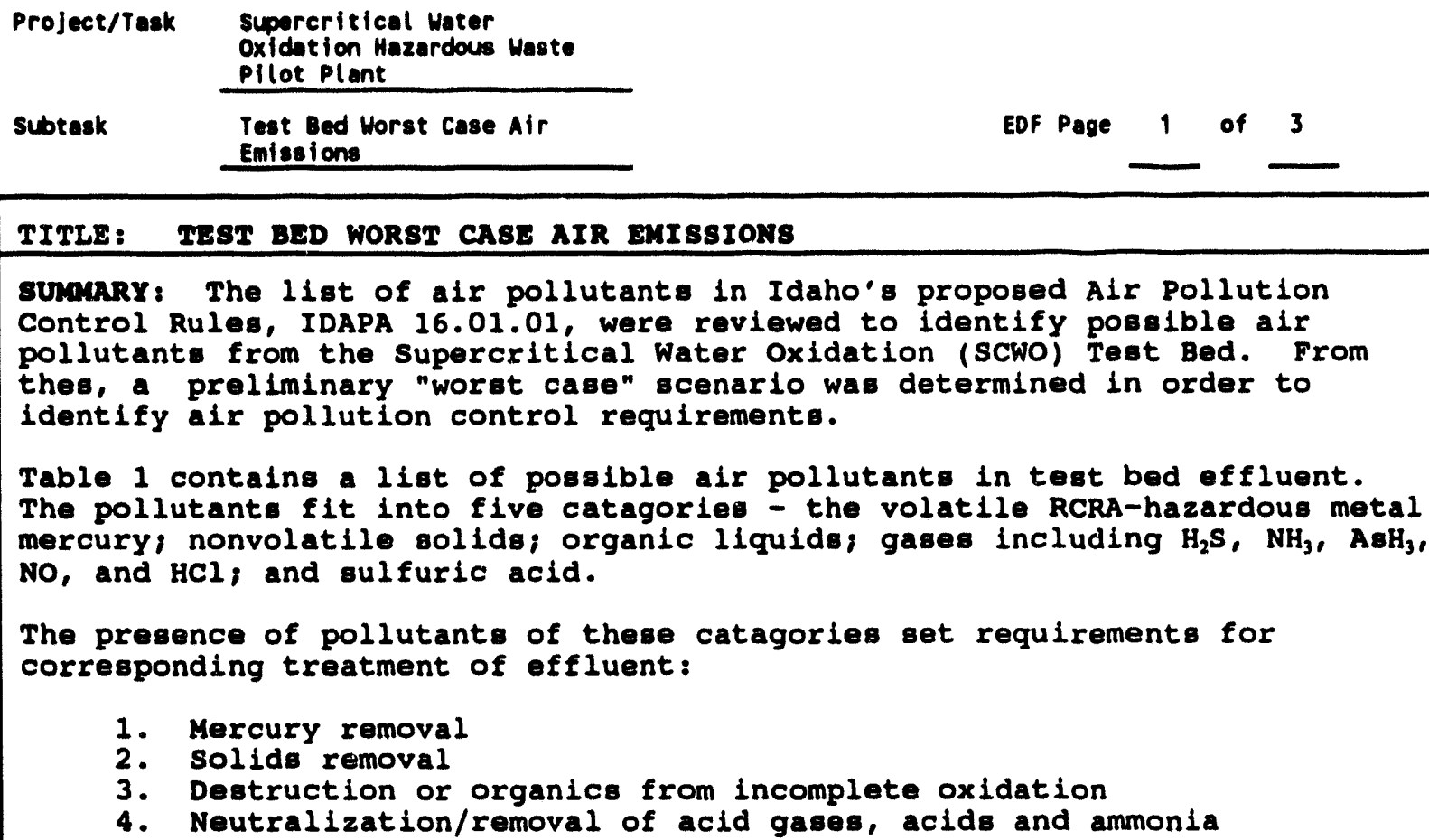

Test Bed Horst Case Air Emissions

subtask

\section{TITLE: TEST BED WORST CASE AIR BHISSIONS}

sunaray: The list of air pollutants in Idaho's proposed Air Pollution Control Rules, IDAPA 16.01.01, were reviewed to identify poseible alr pollutante from the supercxitical Water Oxidation (SCWO) Test Bed. From thes, a preliminary "worst case" scenario was determined in order to identify air poliution control requirements.

Table 1 contains a list of posaible air pollutants in test bed effluent. The pollutants fit into five catagories - the volatile RCRA-hazardous metal mercury; nonvolatile solids; organic liquids; gases including $\mathrm{H}_{2} \mathrm{~S} \mathrm{NH}_{3}, \mathrm{AsH}_{3}$ NO, and $\mathrm{HCl}$; and sulfuric acid.

The presence of pollutants of these catagories set requirements for corresponding treatment of effluent:

EDF Page 1 of 3

The probability of forming arsine is very low because of the high level of oxygen present. Also, No will certainly fall below the $6 \mathrm{lb} / \mathrm{hr}$ EL since, based on sCWO experience only traces of NO, forms, and for the waste series with the most nitrogen, only $3.6 \mathrm{lb} / \mathrm{hr}$ of nitrogen will be in the effluent.

The worst case for mercury and organics removal will be Test waste series 1 , and a worst case effluent composition is given in Table 2 . To achieve a mercury emisgion rate of less than $0.003 \mathrm{lb} / \mathrm{hr}$, and assuming worst case conditions, 938 removal of $\mathrm{Hg}$ would be required. The worst case for $\mathrm{HCl}$ removal is Series 4, TRIMSOL, and 998 removal is required to meet the EL of $0.05 \mathrm{lb} / \mathrm{hr}$.

Distribution (complete C. M. Barnes, J. M. Beller, T. R. Charlton, K. package): M. Garcia, R. W. Marshall, Jr., W. C. Reed, C. Shapiro, H. Welland

Distribution (summary page J. J. McCarthy only):

\begin{tabular}{|c|c|c|}
\hline $\begin{array}{ll}\text { Author } & \text { Dept. } \\
\text { c M. Bgrnes } & \text { B820 } \\
\text { in Bame_ } 3.24 .44\end{array}$ & $\begin{array}{l}\text { Reviewed, Date } \\
\text { D.Jer. J/24/94 } \\
\text { D. M. } \\
\text { Ginosar }\end{array}$ & $\begin{array}{l}\text { Apprgyen l Date } \\
\text { Chariton }\end{array}$ \\
\hline & $\begin{array}{l}\text { EG\&G } \\
\text { Review }\end{array}$ & $\begin{array}{ll}\text { EG\&G } & \text { Date } \\
\text { Approval } & \end{array}$ \\
\hline
\end{tabular}


TABLE 1

\section{POSSIBLE AIR POLLUTANTS IN SCWO EFFLUENT}

\section{Noncarcinogen}

Byproducts of incomplete oxidation

Acetic acid

Ammonia

Arsine

Dichlorethane

Dichloroethylene

Ethylene dichloride

Formic acid

Hydrogen sulfide

Nitrous oxide

Toluene

Trichloroethylene
Directly added to feed

Acetone

Biphenyl

Chromium compounds

Dibutyl phosphate

Diethanolamine

Ethanolamine

Mercury and $\mathrm{Hg}$ compounds

Methyl alcohol

Phenol

Selenium and Se compounds

Silver compounds

$\mathrm{NaOH}$

Tributyl phosphate
Oxidation Products

Boron oxide

Calcium carbonate

Calcium hydroxide

Calcium oxide

Calcium silicate

Calcium sulfate

Hydrogen chloride

Phosphorus pentoxide

Sulphuric acid

Zinc chloride

Zinc oxide

\section{Carcinogen}

Byproducts of incomplete oxidation

Directly added to feed

Oxidation Products

Arsenic compounds

Carbon tetrachloride

Chloroform

Benzene

Chloromethane

Cadmium and $\mathrm{Cd}$ compounds

1,1 Dichlorethylene

1,2 Dichlorethylene

Dichlormethane

Formaldehyde

1,1,2,2 Tetrachloroethane

Tetrachloroethylene

Trichloroethylene

Vinyl Chloride 
TABLE 2

\section{WORST CASE EFFLUENT COMPOSITION}

Basis:

8.6 weight\% benzene in water

3 times stoichiometric $\mathrm{O}_{2}$

Maximum benzene case based on no oxidation

Minimum benzene case based on $99.99 \%$ destruction efficiency

Assume all $\mathrm{O}_{2}$ and $\mathrm{CO}_{2}$ in gaseous phase at final letdown

Water calculated from partial pressure at $35^{\circ} \mathrm{C}$ and total pressure of 15 psia

Compositional range: (lb/hr)

$\begin{array}{lll} & \text { Minimum } & \text { Maximum } \\ \text { Benzene } & 0.0036 & 35.5 \\ \mathrm{O}_{2} & 218 & 327 \\ \mathrm{CO}_{2} & 120.2 & 0 \\ \mathrm{H}_{2} \mathrm{O} & 6.5 & 7.5 \quad \text { (this should be updated according to latest } \\ \mathrm{Hg} & 0 & 0.0406\end{array}$

Required organic destruction for EL of $0.0008 \mathrm{lb} / \mathrm{hr}$ benzene:

$$
(35.5-0.0008) / 35.5=99.998 \%
$$

Required $\mathrm{Hg}$ removal for $\mathrm{EL}$ of $0.003 \mathrm{lb} / \mathrm{hr}$ :

$$
(0.0406-0.003) / 0.0406=92.7 \%
$$



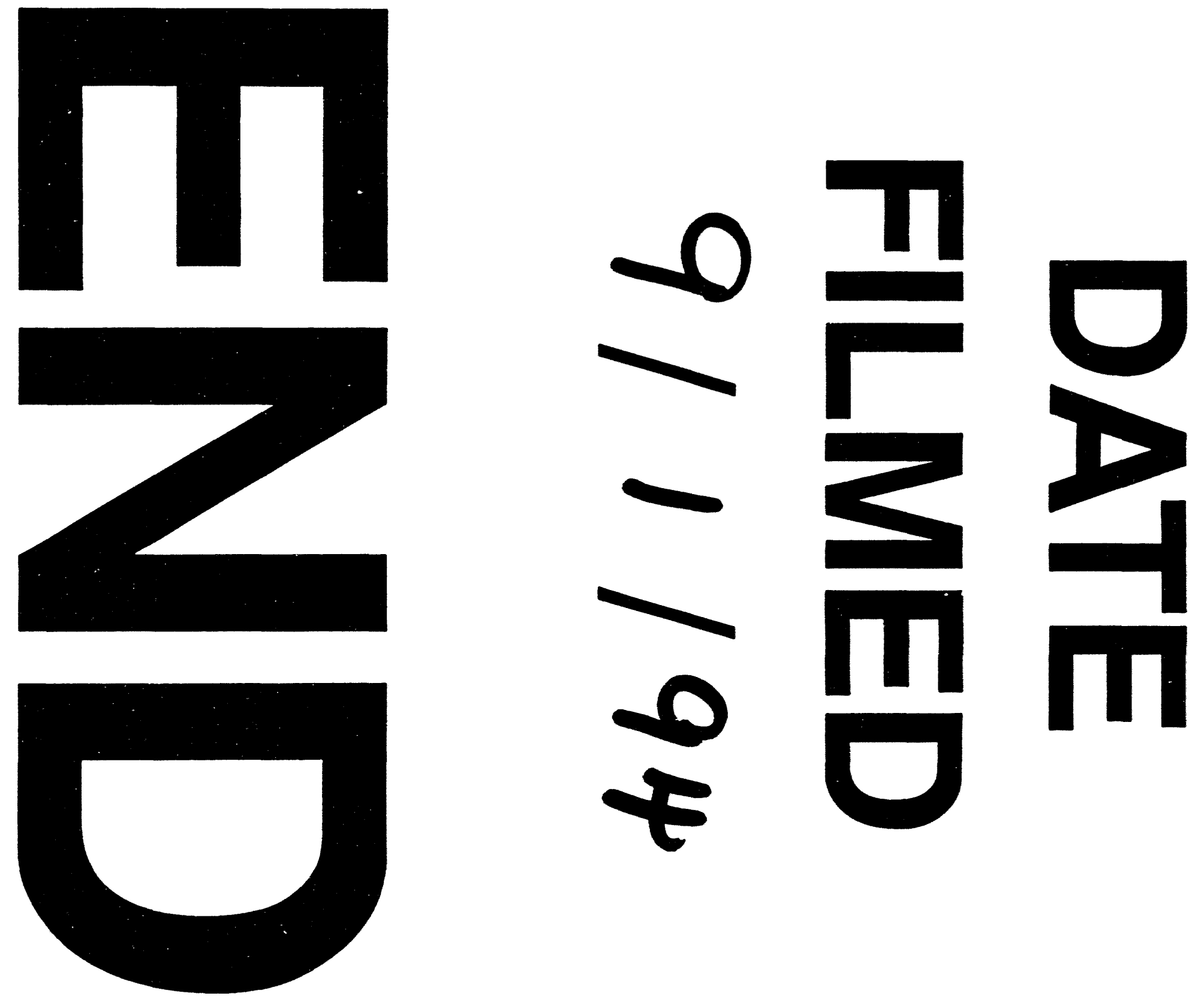
